\title{
Systems approaches to study root architecture dynamics
}

\author{
Candela Cuesta ${ }^{1}$, Krzysztof Wabnik ${ }^{2}$ and Eva Benková ${ }^{1,3 *}$ \\ 1 Institute of Science and Technology Austria, Klosterneuburg, Austria \\ 2 Department of Plant Systems Biology, Flanders Institute for Biotechnology (VIB) and Department of Plant Biotechnology and Genetics, Ghent University, \\ Technologiepark, Gent, Belgium \\ ${ }^{3}$ Mendel Centre for Plant Genomics and Proteomics, Masaryk University, Brno, Czech Republic
}

Edited by:

Wolfgang Schmidt, Academia Sinica, Taiwan

Reviewed by:

Masanori Arita, University of Tokyo, Japan

Akiko Satake, Hokkaido University, Japan

\section{*Correspondence:}

Eva Benková, Institute of Science and Technology Austria,

Am Campus 1,

3400 Klosterneuburg, Austria

e-mail: eva.benkova@ist.ac.at
The plant root system is essential for providing anchorage to the soil, supplying minerals and water, and synthesizing metabolites. It is a dynamic organ modulated by external cues such as environmental signals, water and nutrients availability, salinity and others. Lateral roots (LRs) are initiated from the primary root post-embryonically, after which they progress through discrete developmental stages which can be independently controlled, providing a high level of plasticity during root system formation. Within this review, main contributions are presented, from the classical forward genetic screens to the more recent high-throughput approaches, combined with computer model predictions, dissecting how LRs and thereby root system architecture is established and developed.

Keywords: root system, lateral root, genetic screening, transcript profiling, genomics studies, systems approach
The root as an underground organ is of vital importance for plant life. It provides anchorage to the soil, supplies minerals and water, synthesizes metabolites, and interacts with symbiotic organisms (Den Herder et al., 2010). The root system architecture is shaped by the environmental signals and other external cues, which modulate root growth direction and kinetics (Luschnig et al., 1998; Lavenus et al., 2013), as well as its surface by affecting root hair growth (Lan et al., 2013) and frequency of branching (Sanz et al., 2011). In particular, formation of lateral roots (LRs) is one of the key determinants of the root architecture with an eminent impact on the efficiency of soil exploitation. For example, nitrate, phosphate, or sulfate availability modulate both primary root growth as well as LR formation and outgrowth (Linkohr et al., 2002; Hubberten et al., 2012), demonstrating close interconnection between nutrient availability and root architecture. LR organogenesis (Figure 1) is a well-defined process with discrete developmental steps including (i) priming, (ii) initiation, (iii) LR primordia (LRPs) organogenesis, (iv) LR emergence, and (v) activation of the LR apical meristem (Laskowski et al., 1995; Malamy and Benfey, 1997). These distinct developmental phases are under specific control mechanisms, providing a high level of plasticity during root system formation. To shape the root architecture in response to various external cues, plant hormones play an important role of rapid endogenous signal mediators (López-Bucio et al., 2003; Malamy, 2005). The core of this hormonal regulatory network comprises two antagonistically acting molecules: auxin and cytokinin. Auxin as a key stimulatory factor triggers and coordinates LR organogenesis, while cytokinin interferes with both initiation and LRP organogenesis (Benková et al., 2003; Laplaze et al., 2007; Fukaki and Tasaka, 2009; Bielach et al., 2012a).

The exploration of the development of the root system has been confronted with various obstacles, such as the interplay between primary root growth and LR organogenesis, and technical challenges, such as limitations on isolating specific tissue layers of LRP which are hidden within tissues of the primary root. Therefore, studying root growth has required the development and implementation of specific tools and approaches. On other hand, some experimental advantages are obvious, e.g., there is a defined spatio-temporal frame or developmental window when cells are competent to initiate LRs (Dubrovsky et al., 2006, 2011), a capacity of ectopic induction and synchronization of LR initiation along the primary root by hormone application (Himanen et al., 2002), or easy-to-perform imaging of the LRPs.

Recently, root development research experienced great revival, especially because of an implementation of new generation imaging techniques and high-throughput approaches. The aim of this review is to acknowledge those techniques that have contributed to the deeper understanding of the development of the root system, as well as to present the most novel tools and their application potential. To present a broad picture of the formation and development of the root system we have discussed some of most prominent approaches for studying LR development that range from live-based methodologies to high-throughput technologies, combined with predictions from computer models of LR morphogenesis.

\section{LATERAL ROOT FORMATION AND DEVELOPMENT IN LIGHT OF REAL-TIME IMAGING}

Implementation of the modern imaging techniques enabled to address longstanding questions on the LR organogenesis at qualitatively new level. In particular real-time imaging with high tissue resolution have provided a close spatio-temporal view on the early phases of lateral root initiation (LRI) and brought new insights into the dynamics of LR organogenesis.

In Arabidopsis thaliana, within the developmental window the position of the newly initiated LR is defined, i.e., the root zone where the cells exhibit the highest competence to initiate LRs (Dubrovsky et al., 2006). Early attempts to monitor LRI dynamics revealed that early events resulting in LRI correlate 


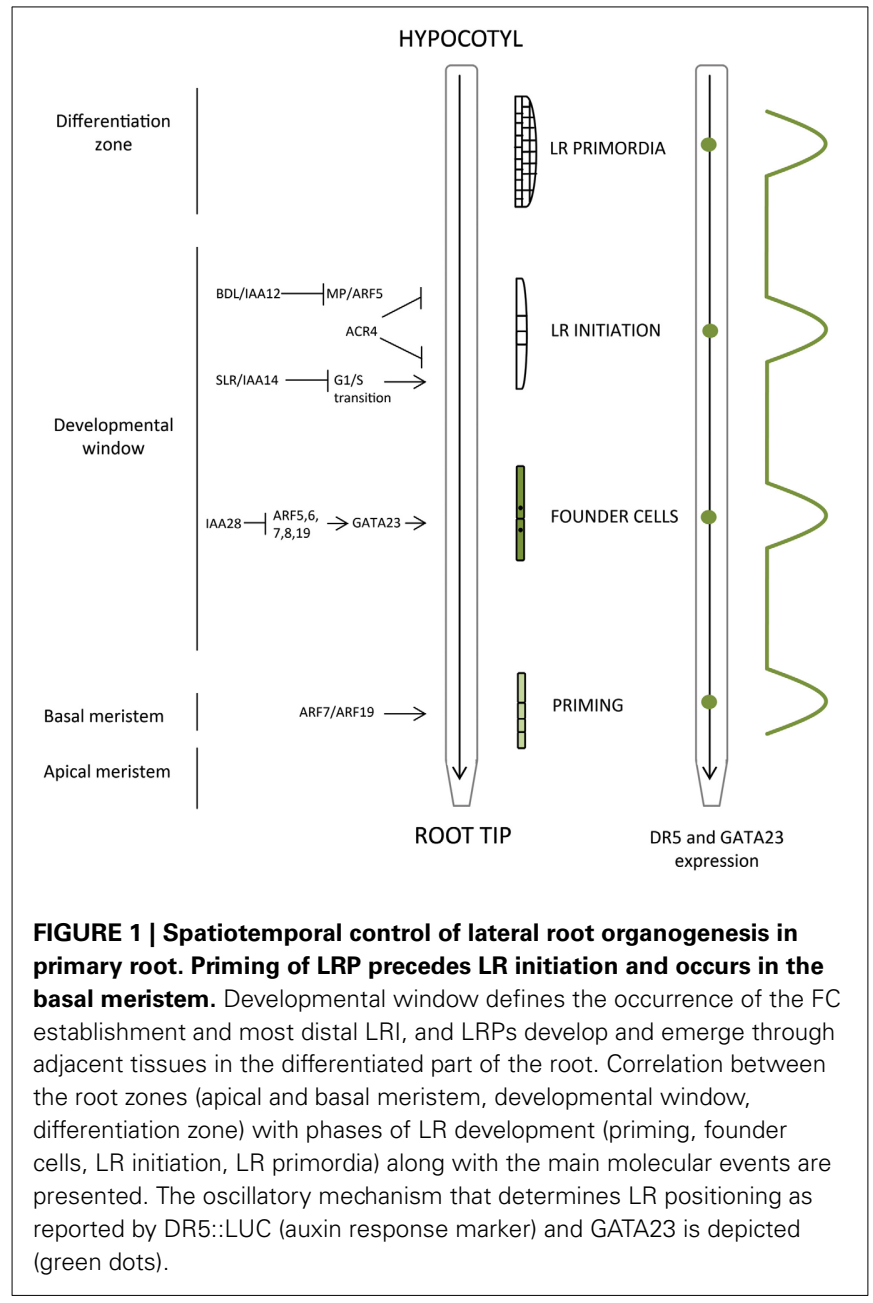

with regular fluctuations of an auxin sensitive reporter DR5:: $\beta$ glucuronidase (GUS) in the protoxylem cells in the basal root meristem (De Smet et al., 2007). This recurrent enhancement of auxin activity, named priming, occurs with regular intervals of approximately $15 \mathrm{~h}$, corresponding with the frequency of LRI during root growth. Later by the implementation of a real-time monitoring system using the DR5::LUCIFERASE reporter, more detailed studies of LRI dynamics could be performed (MorenoRisueno et al., 2010). Luciferase imaging confirmed the oscillatory nature of the auxin response in the root, and correlated pulses of luciferase activity with prebranch sites that precede the establishment of static points where LRs are formed (Moreno-Risueno et al., 2010). Application of high-throughput transcriptome profiling synchronized with the oscillatory auxin response led to the discovery that besides auxin, a complex network of oscillating transcription factors contributes in setting up a prebranch site.

Another approach that combined the high end real-time imaging with computational modeling pointed out that the change in a shape of root cells as a consequence of gravitropic or mechanical bending redirects auxin flow toward pericycle cells, thereby resulting in an auxin accumulation in these cells that triggers LRI (Ditengou et al., 2008; Laskowski et al., 2008).
The next step in LR formation after priming and founder cell (FC) specification is the initiation of primordia organogenesis by series of anticlinal divisions. The identification of mutants in which despite FC establishment no LRI takes place (Celenza et al., 1995; DiDonato et al., 2004; Dubrovsky et al., 2008; De Rybel et al., 2010) indicates that the specification of FCs does not lead by default to LRI and that these two events might be uncoupled. Real-time imaging of LRI has shown that auxin continues to accumulate in the FCs, until it reaches a maximum just prior the actual initiation event (De Rybel et al., 2010). Later, an auxin reflux pathway, which is transiently established during the early phases of LRI, was found. This reflux via the PIN-formed (PIN3) auxin efflux carrier reinforces the auxin flow from the endodermal cells to the FCs, thereby enabling to reach the auxin threshold required to transit from founder to LRI phases (Marhavý et al., 2013).

LRP organogenesis continues by a series of cell divisions and differentiation coordinated by auxin. An auxin gradient with a maximum at the primordia tip is instructive for proper organ formation, and modulation of auxin distribution interferes with the progress of LR organogenesis (Benková et al., 2003). High resolution imaging of LRPs in real time turned out to be a powerful approach to bring further insights into the mechanisms controlling LRP organogenesis. 3D/4D image analysis (Lucas et al., 2013) revealed that early stage LRPs exhibit tangential divisions that create a ring of cells enclosing a population of rapidly dividing cells. The division patterns in the latter cell population during LRP morphogenesis are not stereotypical, although the shape of new LRPs is highly conserved. Interestingly, manipulating the properties of overlaying tissues disrupted LRP morphogenesis, indicating that the interaction with overlaying tissues might be more important for LRP morphogenesis than the precise division pattern.

Recently, monitoring LRP development when cytokinin is present revealed a rapid change in the PIN1 auxin efflux carriers expression caused by this hormone. Based on these observations cytokinin was proposed to interfere with LR organogenesis through regulation of the constitutive cycling of PIN1 by its alternative sorting to lytic vacuoles and subsequent degradation (Marhavý et al., 2011).

Similarly, understanding LR emergence and their interplay with surrounding tissues rapidly advanced with improved imaging techniques. In light of these observations it became clear that LR emergence is a tightly coordinated process during which auxin acts as local inductive signal to control cell separation in overlaying tissues (Swarup et al., 2008; Péret et al., 2012; Kumpf et al., 2013; Lucas et al., 2013). Moreover, applying real-time imaging improved our view on the acquisition of LR gravity sensing properties when emerging out of the parental root. The regulation of the gravitropic response of LRs, defining the gravitropic setpoint angle, is crucial for the radial expansion of the root system (plagiotropism). Real-time analysis demonstrated that acquiring a gravity sensitive stage strongly correlates with the modulation of asymmetric auxin transport rates in LR columella, the differentiation of statoliths and the establishment of a connection to the primary root vasculature (Guyomarc'h et al., 2012; Rosquete et al., 2013). 


\section{GENETIC STUDIES}

A traditional strategy to identify the molecular components and mechanisms involved in a developmental process is forward genetics. Chemical agents (e.g., ethyl methanesulfonate) or radiation are used to induce mutations causing a certain phenotype, and using a mapping strategy the responsible gene can be identified (Lukowitz et al., 2000).

This approach has been successfully applied to reveal key components of LR formation (Table 1). Early screens based on the LR phenotype by Celenza et al. (1995) identified the aberrant lateral root formation (alf) mutants. Three different alf mutants were characterized: (i) alf1-1, with an increased number of LRs caused by IAA overproduction, turned out to be an allele of SUPERROOT1 (SUR1) and ROOTY1 (RTY1) [Boerjan et al. (1995) and King et al. (1995), respectively]; (ii) alf3-1, with arrested LRPs, that can be rescued by exogenous application of auxin; and (iii) alf4-1, unable to form LRs. Further work was done on the latter mutant by DiDonato et al. (2004), showing that ALF4 is required to maintain the developmental plasticity of pericycle cells and their meristem-like properties. Hence, alf4-1 can perceive the LR induction signal but initiation cannot proceed because the xylem-adjacent pericycle cells cannot divide, since a mitotically active state is not maintained in the mutant. Another screen based on LR abundance has identified additional components specifically involved in the early phases of LRI, such as Reduces Lateral root Formation (RLF) (Ikeyama et al., 2010). The $R L F$ gene codes for a cytosolic protein containing a cytochrome b5-like heme/steroid binding domain, and it seems to be involved in the activation of pericycle cell divisions at LRI sites downstream of auxin signaling.

Besides root oriented screens, investigation of other plant phenotypes (e.g., auxin defects, shoot appearance) has revealed remarkable components of LR formation and development. A screen for mutants defective in the shoot gravitropic response led to the identification of the solitary root-1 (slr-1) mutant that completely lacks LRs (Fukaki et al., 2002). The mutation in IAA14 belonging to the $A u x / I A A$ auxin signaling repressor gene family stabilizes the IAA14 protein and as a consequence the auxin dependent initiation of LRs is disrupted. In efforts to reveal additional components of this SLR-mediated pathway, a suppressor screening was conducted on $s l r-1$, identifying mutants such as $s l r-$ $1 R 1$ (Fukaki et al., 2002) or SSL2 (Fukaki et al., 2006). In the case of $s l r-1 R 1$, an intragenic suppressor of $s l r-1$, root hair formation is restored, but LR formation gets poorly recovered, indicating that LR and root hair formation require different mechanisms involving SLR/IAA14. The second mutant identified (pickel/ssl2) is an extragenic suppressor of $s l r-1$. PICKEL/SSL2 is a homolog of the animal chromatin-remodeling factor CHD3/Mi-2, implicating a role for chromatin remodeling mediated by PKL/SSL2 in the negative regulation of auxin-mediated LR formation in Arabidopsis.

Also screens targeting auxin signaling pathway resulted in the identification of mutants defective in LR organogenesis, highlighting the importance of auxin signaling in LR formation. That is the case for the auxin receptors TIR1 and related F box proteins AFB1, 2 and 3 (Dharmasiri et al., 2005). The loss of these genes resulted in a progressive decrease in auxin response during
Table 1 | Summary of the genes involved in LR initiation and development, including those summarized in Casimiro et al. (2003), De Smet et al. (2006) and Péret et al. (2009).

\begin{tabular}{|c|c|c|c|}
\hline Gene & Mutant & LR phenotype & Publication \\
\hline ABA1 & $a b a 1$ & Inhibition of LR & $\begin{array}{l}\text { Vartanian, 1996; } \\
\text { Signora et al., } 2001\end{array}$ \\
\hline $\mathrm{ABI3}$ & abi3-6 & $\begin{array}{l}\text { Required for } \\
\text { correct auxin } \\
\text { response in LR }\end{array}$ & Brady et al., 2003 \\
\hline$A B \mid 4$ & $a b i 4$ & Inhibition of LR & Signora et al., 2001 \\
\hline$A B \mid 5$ & $a b i 5$ & Inhibition of LR & Signora et al., 2001 \\
\hline ACR4* & acr4 & Increased LR & De Smet et al., 2008 \\
\hline AFB1 & $a f b 1$ & $\begin{array}{l}\text { Decrease auxin } \\
\text { response on LR }\end{array}$ & $\begin{array}{l}\text { Dharmasiri et al., } \\
2005\end{array}$ \\
\hline AFB2 & $a f b 2$ & & \\
\hline AFB3 & afb3 & & \\
\hline AGB1 & $a g b 1-1, a g b 1-2$ & Increased LR & Ullah et al., 2003 \\
\hline $\begin{array}{l}\text { ALF1/SUR1/ } \\
\text { RTY1* }\end{array}$ & alf1-1/sur1/rty1 & Increased LR & $\begin{array}{l}\text { Boerjan et al., 1995; } \\
\text { Celenza et al., 1995; } \\
\text { King et al., } 1995\end{array}$ \\
\hline ALF3* & alf3-1 & Arrested LR & Celenza et al., 1995 \\
\hline ALF4* & alf4-1 & Lack of LR & $\begin{array}{l}\text { Celenza et al., 1995; } \\
\text { DiDonato et al., } 2004\end{array}$ \\
\hline ARABIDILLO & arabidillo1/2 & Reduced LR & Coates et al., 2006 \\
\hline ARF7/ARF19* & arf7xarf19 & Lack of LR & $\begin{array}{l}\text { Okushima et al., } \\
2005\end{array}$ \\
\hline \multirow[t]{2}{*}{ ARF8 } & arf8-1 & Increased LR & Tian et al., 2004 \\
\hline & $\begin{array}{l}\text { Overexpression } \\
35 s:: A R F 8\end{array}$ & Reduced LR & \\
\hline ARF 10/16/17 & $\begin{array}{l}\text { Overexpression } \\
\text { ARF10/16/17 }\end{array}$ & Reduced LR & $\begin{array}{l}\text { Mallory et al., 2005; } \\
\text { Wang et al., } 2005\end{array}$ \\
\hline ARR3 & $\operatorname{arr3}$ & Reduced LR & To et al., 2004 \\
\hline ARR4 & arr4 & & \\
\hline ARR5 & $\operatorname{arr} 5$ & & \\
\hline ARR6 & $\operatorname{arr} 6$ & & \\
\hline ARR8 & $\operatorname{arr} 8$ & & \\
\hline ARR9 & $\operatorname{arr} 9$ & & \\
\hline ATHB-2 & $\begin{array}{l}35 s:: A T H B-2 \\
\text { reverse ATHB-2 } \\
\text { sequence } \\
35 s:: \alpha A T H B-2\end{array}$ & $\begin{array}{l}\text { Reduced LR } \\
\text { Increased LR }\end{array}$ & Steindler et al., 1999 \\
\hline ATHB-8 & Overexpression & Reduced LR & Baima et al., 2001 \\
\hline$A \cup X 1 *$ & aux1 alleles & Reduced LR & Marchant et al., 2002 \\
\hline AXR1 & axr1-3, axr1-12 & Reduced LR & Lincoln et al., 1990 \\
\hline $\mathrm{AXR} 2^{*}$ & axr2-1/iaa7 & Increased LR & Nagpal et al., 2000 \\
\hline AXR4 & $\begin{array}{l}\text { axr4-1, axr4-2, } \\
\text { axr4-1 axr1-3 }\end{array}$ & Reduced LR & $\begin{array}{l}\text { Hobbie and Estelle, } \\
1995\end{array}$ \\
\hline AXR6 & axr6-1, axr6-2 & Reduced LR & Hobbie et al., 2000 \\
\hline
\end{tabular}

(Continued) 


\section{Table 1 | Continued}

\begin{tabular}{|c|c|c|c|}
\hline Gene & Mutant & LR phenotype & Publication \\
\hline $\mathrm{BR} \times 2$ & $b r x-2$ & $\begin{array}{l}\text { Increased LR (on } \\
\text { cytokinin) }\end{array}$ & Li et al., 2009 \\
\hline CEG & ceg & Increased LR & Dong et al., 2006 \\
\hline CKX1 & $\begin{array}{l}\text { Overexpression } \\
35 s:: C K X 1\end{array}$ & Increased LR & Werner et al., 2003 \\
\hline CKX3 & $\begin{array}{l}\text { Overexpression } \\
35 s:: C K X 1\end{array}$ & Increased LR & Werner et al., 2003 \\
\hline \multirow[t]{2}{*}{ DFL1 } & $\begin{array}{l}\text { dfl1-D, sense } \\
35 s:: D F L 1\end{array}$ & Reduced LR & \multirow[t]{2}{*}{$\begin{array}{l}\text { Nakazawa et al., } \\
2001\end{array}$} \\
\hline & $\begin{array}{l}\text { antisense } \\
35 s:: D F L 1 a s\end{array}$ & Increased LR & \\
\hline $\mathrm{E} 2 \mathrm{Fa}^{*}$ & $\mathrm{E} 2 \mathrm{Fa}$ & Reduced LR & $\begin{array}{l}\text { Berckmans et al., } \\
2011\end{array}$ \\
\hline ERA1 & era1-2 & Increased LR & Brady et al., 2003 \\
\hline ETA3 & eta3 & Reduced LR & Gray et al., 2003 \\
\hline GNOM & gnom alleles & Reduced LR & Geldner et al., 2004 \\
\hline GPA1 & gра1-1, gра1-2 & Reduced LR & Ullah et al., 2003 \\
\hline HAT2 & Overexpression & $\begin{array}{l}\text { Reduced LR } \\
\text { elongation }\end{array}$ & Sawa et al., 2002 \\
\hline HOBBIT & hbt allele & $\begin{array}{l}\text { LR meristem } \\
\text { defect }\end{array}$ & $\begin{array}{l}\text { Willemsen et al., } \\
1998\end{array}$ \\
\hline HY5 & hy5-1, hy5-Ks50 & Increased LR & Oyama et al., 1997 \\
\hline IAA1 & axr5-1 & $\begin{array}{l}\text { Reduced LR (on } \\
\text { auxin) }\end{array}$ & Yang et al., 2004 \\
\hline \multirow[t]{2}{*}{ IAA3* } & shy $2-2$ & Reduced LR & \multirow[t]{2}{*}{ Tian and Reed, 1999} \\
\hline & shy $2-22$, shy $2-24$ & Increased LR & \\
\hline \multirow[t]{3}{*}{ IAA14* } & $s / r-1$ & Lack of LR & \multirow[t]{2}{*}{ Fukaki et al., 2002} \\
\hline & $s \mid r-1 R 1$ & $\begin{array}{l}\text { Poorly restored } \\
\text { LR }\end{array}$ & \\
\hline & PICKLE/SSL2 & $\begin{array}{l}\text { Partial restored } \\
\text { LR }\end{array}$ & Fukaki et al., 2006 \\
\hline IAA18 & iaa18/crane & Reduced LR & Uehara et al., 2008 \\
\hline IAA19 & $m s g 2-1$ & Reduced LR & $\begin{array}{l}\text { Tatematsu et al., } \\
2004\end{array}$ \\
\hline IAA28* & iaa28-1 & Reduced LR & Rogg et al., 2001 \\
\hline IAR3 & ilr1 iar3 ill2 & Reduced LR & Rampey et al., 2004 \\
\hline \multicolumn{4}{|l|}{ ILL2 } \\
\hline \multicolumn{4}{|l|}{ ILR1 } \\
\hline ILR2 & ilr2-1 & Reduced LR & Magidin et al., 2003 \\
\hline KNAT6 & $35 s:: R N A i$ & Increased LR & Dean et al., 2004 \\
\hline KRP2 & $35 s:: K R P 2$ & Reduced LR & Himanen et al., 2002 \\
\hline LAX3* & $1 a \times 3$ & Reduced LR & Swarup et al., 2008 \\
\hline
\end{tabular}

(Continued)
Table 1 | Continued

\begin{tabular}{|c|c|c|c|}
\hline Gene & Mutant & LR phenotype & Publication \\
\hline LIN1 & $\operatorname{lin} 1$ & $\begin{array}{l}\text { No LR } \\
\text { repression }\end{array}$ & $\begin{array}{l}\text { Malamy and Ryan, } \\
2001\end{array}$ \\
\hline MRP5* & mrp5-1 & Increased LR & Gaedeke et al., 2001 \\
\hline \multirow[t]{2}{*}{ NAC1 } & $\begin{array}{l}\text { Antisense } \\
35 s:: N A C 1\end{array}$ & Reduced LR & Xie et al., 2002 \\
\hline & $\begin{array}{l}\text { Overexpression } \\
35 s:: N A C 1\end{array}$ & Increased LR & \\
\hline PAS1 & pas1 & Reduced LR & $\begin{array}{l}\text { Faure et al., 1998; } \\
\text { Vittorioso et al., } 1998\end{array}$ \\
\hline PAS2 & pas2 & Increased LR & $\begin{array}{l}\text { Faure et al., 1998; } \\
\text { Bellec et al., } 2003\end{array}$ \\
\hline PAS3 & pas3 & Reduced LR & Faure et al., 1998 \\
\hline PGP4 & pgp4 & Increased LR & Santelia et al., 2005 \\
\hline PIN1* & $\begin{array}{l}\text { Overexpression } \\
35 s:: \text { PIN1 }\end{array}$ & $\begin{array}{l}\text { Delay LR } \\
\text { development }\end{array}$ & Benková et al., 2003 \\
\hline PIN3* & $\begin{array}{l}\operatorname{pin} 1 \text { pin, } 3 \text { pin } 3 \\
\operatorname{pin} 7\end{array}$ & Reduced LR & \\
\hline PIN4 & $\begin{array}{l}\text { pin4 pin7, pin1 } \\
\text { pin4 pin7, pin1 } \\
\text { pin3 pin4 }\end{array}$ & & \\
\hline PIN7* & $\operatorname{pin} 1$ pin 3 pin 7 & & \\
\hline PINOID & $\begin{array}{l}\text { Overexpression } \\
35 s:: P I D\end{array}$ & Reduced LR & $\begin{array}{l}\text { Christensen et al., } \\
\text { 2000; Benjamins } \\
\text { et al., } 2001\end{array}$ \\
\hline $\begin{array}{l}\text { PLT1 } \\
\text { PLT2 }\end{array}$ & plt1 plt2 & Increased LR & Aida et al., 2004 \\
\hline PXA1 & pxa1 & Reduced LR & Zolman et al., 2001 \\
\hline RanBP1c & $\begin{array}{l}\text { Antisense } \\
\text { AtRanBP1C }\end{array}$ & Reduced LR & Kim et al., 2001 \\
\hline RAV1 & Overexpression & $\begin{array}{l}\text { Delay LR } \\
\text { development }\end{array}$ & Hu et al., 2004 \\
\hline RCN1 & $\operatorname{ren} 1$ & $\begin{array}{l}\text { LR growth less } \\
\text { NPA sensitive }\end{array}$ & Rashotte et al., 2001 \\
\hline RIB1 & rib1 & Increased LR & $\begin{array}{l}\text { Poupart and Waddell, } \\
2000\end{array}$ \\
\hline RLF* & $r l f-1$ & Reduced LR & Ikeyama et al., 2010 \\
\hline RML1 & $\mathrm{rm} / 1$ & Arrested LR & Cheng et al., 1995 \\
\hline RML2 & $r m / 2$ & Lack of LR & Cheng et al., 1995 \\
\hline ROP2 & $\begin{array}{l}\text { CA-rop2 } \\
\text { DN-rop2 }\end{array}$ & $\begin{array}{l}\text { Increased LR } \\
\text { Reduced LR }\end{array}$ & Li et al., 2001 \\
\hline SBR & $s b r$ & Reduced LR & $\begin{array}{l}\text { Subramanian et al., } \\
2002\end{array}$ \\
\hline
\end{tabular}

(Continued) 
Table 1 | Continued

\begin{tabular}{|c|c|c|c|}
\hline Gene & Mutant & LR phenotype & Publication \\
\hline SEU & seu-3 & Reduced LR & $\begin{array}{l}\text { Pfluger and } \\
\text { Zambryski, } 2004\end{array}$ \\
\hline \multirow[t]{2}{*}{ SINAT5 } & $\begin{array}{l}\text { Overexpression } \\
35 s:: \text { SINAT5 }\end{array}$ & Reduced LR & Xie et al., 2002 \\
\hline & $\begin{array}{l}\text { Dominant } \\
\text { negative } \\
\text { 35s::SINAT5 } \\
\text { (C49S) }\end{array}$ & Increased LR & \\
\hline SUR1 & sur1 & Increased LR & Seo et al., 1998 \\
\hline SUR2 & sur2/rnt1 & Increased LR & $\begin{array}{l}\text { Delarue et al., 1998; } \\
\text { Barlier et al., 2000; } \\
\text { Bak et al., } 2001\end{array}$ \\
\hline TIR1 & tir $1-1$ & Reduced LR & $\begin{array}{l}\text { Ruegger et al., 1998; } \\
\text { Dharmasiri et al., } \\
2005\end{array}$ \\
\hline TIR3 (BIG) & $\begin{array}{l}\text { tir3-1, } \\
\text { asa1/umb1 }\end{array}$ & Reduced LR & $\begin{array}{l}\text { Ruegger et al., 1997; } \\
\text { Gil et al., 2001; } \\
\text { Kanyuka et al., } 2003\end{array}$ \\
\hline WAK4 & $\begin{array}{l}\text { DEX-induced } \\
\text { WAK4 antisense }\end{array}$ & $\begin{array}{l}\text { Inhibition LR } \\
\text { development }\end{array}$ & Lally et al., 2001 \\
\hline ХВАТ32 & xbat32-1 & Reduced LR & Nodzon et al., 2004 \\
\hline XPL1 & xipotl & Increased LR & $\begin{array}{l}\text { Cruz-Ramírez et al., } \\
2004\end{array}$ \\
\hline YDK1 & $\begin{array}{l}y d k 1-D, \\
35 s:: Y D K 1\end{array}$ & Reduced LR & Takase et al., 2004 \\
\hline
\end{tabular}

${ }^{*}$ Genes discussed within this review.

LR formation. Several Aux/IAA gain-of-function mutants, like shy2/iaa3 (Tian and Reed, 1999) or iaa28-1 (Rogg et al., 2001) exhibited dramatically reduced number of LRs, or like axr21/iaa7 (Nagpal et al., 2000) showed an increased number of LRs. Similarly, the forward genetics approach has been employed to seek for new molecular components mediating the interaction between the auxin-cytokinin pathways during LR formation (Bielach et al., 2012b). Several primordia on auxin and cytokinin (pac) mutants in which the basal LRI process was not affected, but a cytokinin resistance phenotype appeared in the presence of auxin, might reveal new players balancing the auxin-cytokinin developmental output.

An alternative strategy is the reverse genetics approach, which is the analysis of mutants in genes selected based on prior knowledge about their role in specific pathways connected with LR formation. That is the case of the Auxin Response Factor (ARF) gene family, encoding transcriptional regulators that are core components of the auxin signaling pathway (Ulmasov et al., 1999). A PCR-based screening approach was conducted, identifying T-DNA insertions affecting the ARF genes (Okushima et al., 2005). By mutant phenotype characterization of several members of this family (specifically ARF7 and ARF19), their role in LR formation was discovered. Similarly, by detailed mutant analyses the function of AUX1 and LAX3 auxin influx and PIN1, PIN3, PIN7, PGP1 and PGP19 efflux transporters in different phases of LR organogenesis has been recognized (Gaedeke et al., 2001; Marchant et al., 2002; Benková et al., 2003; Mravec et al., 2008; Swarup et al., 2008).

\section{PROTEIN INTERACTION STUDIES}

The lasting challenge in elucidating how LR formation is controlled is a complete dissection of the regulatory pathway components. DNA-protein or protein-protein interaction studies, such as yeast one-hybrid or yeast two-hybrid, are powerful approaches to uncover more new molecular players. By implementing this approach in the study of LR formation and development, a direct molecular link between auxin signaling, cell cycle machinery and LRI has been shown (Berckmans et al., 2011). The E2Fa transcription factor (regulator of cell cycle initiation) has been identified as a direct target of the LATERAL ORGAN BOUNDARY DOMAIN18/ASYMMETRIC LEAVES2-LIKE20 (LBD18/ASL20) transcription factor downstream of auxin signaling and its role in triggering the first asymmetric division during LRI has been demonstrated (Berckmans et al., 2011). Additionally, by tandem affinity purification (protein-protein interaction) other proteins involved were identified, including LBD33. The data suggest that a LBD18/LBD33 dimer is necessary for $E 2 F a$ expression.

\section{TRANSCRIPT PROFILING STUDIES}

Genome-wide transcript profiling is a high-throughput technology which enables the efficient evaluation of the complete transcript regulation in a certain process (Hennig et al., 2003). Besides particular genes, the identification and analysis of clusters of co-expressed genes might provide important insights on the physical or functional connection between gene products during the regulation of certain developmental process.

The true challenge in identifying regulatory genes involved in LR organogenesis by genome-wide profiling arises from the fact that LRI is restricted in time and space to a small number of pericycle cells hidden within surrounding primary root tissues. To circumvent this obstacle, a lateral root-inducible system (LRIS) was implemented to boost the frequency of LRI in a largely synchronized manner (Himanen et al., 2002). By combining LRIS with transcript profiling, Himanen et al. (2004) identified genes linked with early phases of LR initiation. Besides expected targets, such as components of the auxin signaling pathway and the cell cycle, clusters of regulatory genes co-regulated in course of the early phases of LRI were recognized. Later, using the LRIS set up, transcript profiles of the control and the lateral rootless solitary root/iaa14 (slr-1) mutant were compared to extract genes linked with LRI (Vanneste et al., 2005). Within the genes identified, cell division-related genes were found $(A P C 8 / C D C 23$, $P C N A 1$ ), directly linking auxin signaling and cell cycle activation during LRI both at the S-phase and the G2-to-M transition. Similarly, by extracting the auxin-regulated genes whose expression is strongly suppressed in the arf7 and arf19 mutants defective in LR organogenesis LATERAL ROOT PRIMORDIUM1 (LRP1), AUXIN-REGULATED GENE INVOLVED IN ORGAN 
SIZE (ARGOS) Or LATERAL ORGAN BOUNDARIES DOMAIN $(L B D)$, family genes were uncovered for their role in LR organogenesis (Okushima et al., 2005).

Although the LRIS significantly increased the frequency of the LRIs, the limitation of tissue specificity was not overcome, since the material used included the whole root segment and contaminating tissues. Considering that a few cells within the pericycle layer are involved in a process such as LR formation, it is very likely that some important regulators could be missed. An elegant solution for this appeared to be an implementation of the Fluorescent Activated Cell Sorting (FACS) technique in combination with transcriptome profiling. To monitor the transcriptome of the xylem pole pericycle cells exclusively, the Gal4-GFP enhancer trap line J0121 with pericycle-specific expression was used (Laplaze et al., 2005). This improved strategy led to the identification of the membrane-localized receptor-like kinase ARABIDOPSIS CRINKLY4 (ACR4), specifically transcribed in the small daughter cell after the first asymmetric pericycle cell division. The ACR4 is a key factor in promoting formative cell divisions in the pericycle, as well as in constraining the number of these divisions once organogenesis has been started (De Smet et al., 2008).

Later phases of LR development have also been targeted by transcript profiling studies (i.e., high-throughput quantitative RT-PCR). Namely, impact of the environmental signals, such as salt stress on primordia development has been examined (Duan et al., 2013). It was disclosed that the water stress-associated hormone abscisic acid (ABA) mediates suppression of LR emergence, acting primarily at the endodermis by tissue-specific ABA signaling pathways.

With the extensive increase of data generated by genome-wide profiling interesting targets might be easily overlooked. Hence, specialized algorithms and computational pipelines are developed to refine data mining and evaluation. A recently released spatio-temporal transcriptional map of the Arabidopsis root (the RootMap) (Brady et al., 2007) became an outstanding tool for evaluating expression patterns and gene correlations in root tissues.

A new tool named Visual Lateral Root Transcriptome Compendium (Visual RTLC) was developed by Parizot et al. (2010), in order to combine and compare the different datasets focused on LR organogenesis. These new appearing methods for data mining provide great opportunities to scale up the identification of novel regulators of LR organogenesis.

\section{CHEMICAL GENOMICS}

Using the above mentioned approaches, crucial components of the LR regulation have been identified, and functional connections between key regulatory pathways (auxin, cytokinin, cell cycle-related), underlying root system architecture control, have been recognized.

Lately, the chemical biology opened new ways to study biological systems. The ability of chemical compounds to enhance, mimic, interfere or block a specific developmental process rises as a powerful tool to discover new regulatory components. The chemical approach is based on the ability of small synthetic molecules to modify the activity of proteins or pathways, resulting in the understanding of the protein function at a level that would be difficult to achieve through gene-based perturbation (Robert et al., 2009). Additionally, a tight temporal control can be accomplished, allowing for instance to overcome limitations related to mutational approaches (e.g., the long-term effect of disrupting the process can lead to lethality). Even more, its combination with other approaches, such as genomic studies, provides an additional power, i.e., the compound effect on a mutant that exhibits a certain phenotype.

The high-throughput screening of the chemical library must first be optimized in order to identify compounds that interfere with a specific developmental process. Aimed at LR organogenesis, an efficient screening method based on the LRIS was established (De Rybel et al., 2012; Audenaert et al., 2013). Using this platform, a naxillin, the non-auxin-like synthetic molecule that induces LR formation, was found as an activator of LRI, being more effective than known synthetic or natural auxins (De Rybel et al., 2012). A chemical approach combined with transcriptome profiling showed that 2581 vs. 401 genes are de-regulated by either auxin or naxilin, respectively, indicating a narrower mechanism of naxillin action when compared to natural auxin (De Rybel et al., 2012). Interestingly, genes involved in the early events of LR development such as GATA23, LBD33, and $L B D 29$, were found to dominate in the naxillin induction profile. Forward genetics resulted in the identification of the naxillin resistant 1 (nar1) mutation in the IBR3 gene, linking naxillin activity with the regulation of the peroxisomal IBA-to-IAA conversion to promote the development of LRs.

\section{COMPUTER MODELING APPROACHES}

Computer models of plant development typically integrate experimentally identified interactions between genes and proteins (regulatory networks) to predict the dynamics of such regulatory networks in the developmental context (Prusinkiewicz and Runions, 2012). Numerous computer models of LR development have been developed to predict putative mechanisms underlying LR morphogenesis. These computer models often integrate experimental observations to identify a minimal mechanistic framework for LRI (Laskowski et al., 2008; Lucas et al., 2008). For example, mechanical deformation of cells was found to occur in the curved region of the primary root and to dramatically affect the size and shape of cells (Ditengou et al., 2008). Laskowski et al. (2008) demonstrated that a subtle change in the cell shape can be instructive for the auxin accumulation in pericycle cells and thus LRI. They also proposed that a feedback between auxin and expression of auxin influx carriers in pericycle cells further builds up this auxin maximum and thus promotes the LRI (Swarup et al., 2005; Laskowski et al., 2008; Péret et al., 2013). Hence, the combination of mechanical tension and auxin feedback on its transport can guide LR development in a self-organizing manner. On the other hand, a model developed by Lucas et al. (2008) suggests that root branching could be controlled by lateral inhibition-a different mechanism that depends on competition or distance between initiation sites and already emerged LR primordia.

Yet another approach attempted to approximate the complexity of sub-cellular regulatory networks that involve crosstalk 
between auxin and cytokinin that could influence both size and location of division and differentiation regions within the primary root as well as the putative periodicity of LR branching (Muraro et al., 2011, 2013). This type of modeling approach serves as a very useful tool to explore how dynamic response of auxin-cytokinin interaction network might change with respect to various mutant-like perturbations.

Finally computer modeling approaches have been applied to understand the physics and mechanics of LR development (Szymanowska-Pulka et al., 2012). Szymanowska-Pulka and colleagues reconstructed LRP morphogenesis based on anatomical observations and proposed a dynamic model of LRP growth that integrates acquisition of cell patterning that determines the final shape of the organ. Similar to that model the combination of live biological imaging, 3D/4D microscopic image reconstruction and dynamic computer model, have also revealed the relevance of coordinated patterning processes occurring in the proximity of the developing LRP that are central to the proper emergence of LRs (Lucas et al., 2013).

Taken together, a synergy of modeling and experimental efforts presented herein is likely to further generate new insights in LR patterning processes and ultimately broaden our understanding of the complex root system architectures.

\section{NOVEL TOOLS AND FUTURE PERSPECTIVES GENETIC STUDIES: SEMI-AUTOMATED PHENOTYPE ANALYSIS}

Developing methods based on acquiring and analyzing developmental processes in real-time are continuously improving. Among others, the implementation of automated systems on root phenotype analyses combined with accurate images is a desirable feature. Fast and high-throughput phenotyping methods were developed to monitor the dynamic of root growth. For instance, the GiA Roots semi-automated software tool for high-throughput analysis of root system architecture (Galkovskyi et al., 2012), the semiautomated 3D in vivo imaging and digital phenotyping pipeline that enables highthroughput and accurate measurements of root system architecture through time (Topp et al., 2013), or the RootNav image analysis tool that allows the semiautomated quantification of complex root system architectures (Pound et al., 2013) were established.

Monitoring gene expression by live microscopy on a large number of specimens growing under controlled conditions to assess their spatio-temporal expression turns out to be another challenge. For this purpose, a microfluidic device (RootArray) where the roots are repeatedly imaged by confocal microscopy, coupled with an image analysis platform that includes automated real-time detection and tracking of samples, has been developed (Busch et al., 2012). This platform provides the ability to compare the reporter gene expression in Arabidopsis roots at tissue level in different developmental zones.

\section{GENETIC STUDIES: FAST-FORWARD GENETICS}

A classical forward genetics approach implies the generation of a large mapping population, a high density of genetic markers for achieving a high resolution mapping, and the screening for recombinants in order to define the genetic interval where the mutation is placed (Lukowitz et al., 2000). Taking the advantage of Next Generation Sequencing, fast-forward genetics (SHOREmap pipeline) has been introduced, where the mapping is directly performed by sequencing (Schneeberger and Weigel, 2011). The SHOREmap pipeline covers from mapping to de novo marker identification during the sequencing process, and final annotation of candidate mutations (Schneeberger et al., 2009), hence profoundly increasing the efficiency of mutant identification.

\section{TRANSCRIPT PROFILING STUDIES: RNA SEQUENCING}

An improved high-throughput transcript profiling technologyRNA sequencing (RNA-seq), has appeared in the last years (Wang et al., 2009). This innovative technique allows the evaluation of the entire transcriptome. It can be used to determine the structure of genes, their splicing patterns and other post-transcriptional modifications, to detect rare and novel transcripts, and to quantify the changing expression levels of each transcript. When compared to microarrays, RNA-seq can detect all expressed genes without the generation of an array of probes, with reduced background noise and large dynamic range. This turned out to be particularly important in species such as tomato, where publicly available microarrays cover only one-third of the complete genome. The RNA-seq approach was used to analyze the transcriptome of tomato roots with the main focus on the spatial patterning and regulation of genes in the root by the hormones cytokinin and auxin. This transcriptome analysis of hormone regulation in tomato root revealed novel genes regulated by each of these hormones and can further be utilized as a reference to conduct future research on tomato roots (Gupta et al., 2013).

\section{CONCLUDING REMARKS}

Root system development is central for the plant to reach optimal growth. Hence, understanding the mechanisms that determine root architecture is of great agronomic importance, since they provide a basis for targeted engineering of plant architecture, e.g., for regulating root growth and branching to exploit less nutritious and arid soils. The availability of genome information has made it possible to study the gene expression on a genome scale, observing the behavior of many genes at a time, and obtaining a comprehensive, dynamic molecular picture. In the systems biology century, the only way to get insight in a developmental process is by combining synergistically the different available techniques, which include the most novel tools and advances. From this perspective, new available approaches are ready to be undertaken to obtain deeper insight in LR formation and development.

\section{ACKNOWLEDGMENTS}

We thank Annick Bleys for help in preparing the manuscript. This work was supported by the European Research Council with a Starting Independent Research grant (ERC-2007-Stg-207362HCPO) and the Czech Science Foundation (GA13-39982S) to Eva Benková. We apologize that, because of space restrictions, the scientific contributions of only a limited number of original articles could be cited and discussed. 


\section{REFERENCES}

Aida, M., Beis, D., Heidstra, R., Willemsen, V., Blilou, I., Galinha, C., et al. (2004). The PLETHORA genes mediate patterning of the Arabidopsis root stem cell niche. Cell 119, 109-120. doi: 10.1016/j.cell.2004.09.018

Audenaert, D., Rybel, B., Nguyen, L., and Beeckman, T. (2013). "Small-molecule screens to study lateral root development," in Plant Organogenesis (Methods in Molecular Biology) Vol. 959, ed I. De Smet (New York, NY: Humana Press), 189-195.

Baima, S., Possenti, M., Matteucci, A., Wisman, E., Altamura, M. M., Ruberti, I., et al. (2001). The Arabidopsis ATHB-8 HD-zip protein acts as a differentiationpromoting transcription factor of the vascular meristems. Plant Physiol. 126, 643-655. doi: 10.1104/pp.126.2.643

Bak, S., Tax, F. E., Feldmann, K. A., Galbraith, D. W., and Feyereisen, R. (2001). CYP83B1, a cytochrome P450 at the metabolic branch point in auxin and indole glucosinolate biosynthesis in Arabidopsis. Plant Cell 13, 101-111. doi: 10.1105/tpc.13.1.101

Barlier, I., Kowalczyk, M., Marchant, A., Ljung, K., Bhalerao, R., Bennett, M., et al. (2000). The SUR2 gene of Arabidopsis thaliana encodes the cytochrome P450 CYP83B1, a modulator of auxin homeostasis. Proc. Natl. Acad. Sci. U.S.A. 97, 14819-14824. doi: 10.1073/pnas.260502697

Bellec, Y., Harrar, Y., Butaeye, C., Darnet, S., Bellini, C., and Faure, J. D. (2003). Pasticcino2 is a protein tyrosine phosphatase- like involved in cell proliferation and differentiation in Arabidopsis. Plant J. 32, 713-722. doi: 10.1046/j.1365313X.2002.01456.X

Benjamins, R., Quint, A., Weijers, D., Hooykaas, P., and Offringa, R. (2001). The PINOID protein kinase regulates organ development in Arabidopsis by enhancing polar auxin transport. Development 128, 4057-4067.

Benková, E., Michniewicz, M., Sauer, M., Teichmann, T., Seifertová, D., Jürgens, G., et al. (2003). Local, efflux-dependent auxin gradients as a common module for plant organ formation. Cell 115, 591-602. doi: 10.1016/S0092-8674(03)0 0924-3

Berckmans, B., Vassileva, V., Schmid, S. P. C., Maes, S., Parizot, B., Naramoto, S., et al. (2011). Auxin-dependent cell cycle reactivation through transcriptional regulation of Arabidopsis E2Fa by lateral organ boundary proteins. Plant Cell 23, 3671-3683. doi: 10.1105/tpc.111.088377

Bielach, A., Podlešáková, K., Marhavý, P., Duclercq, J., Cuesta, C., Müller, B., et al. (2012a). Spatiotemporal regulation of lateral root organogenesis in Arabidopsis by cytokinin. Plant Cell 24, 3967-3981. doi: 10.1105/tpc.112. 103044

Bielach, A., Duclercq, J., Marhavý, P., and Benková, E. (2012b). Genetic approach towards the identification of auxin-cytokinin crosstalk components involved in root development. Philos. Trans. R. Soc. Lond. B. Biol. Sci. 367, 1469-1478. doi: 10.1098/rstb.2011.0233

Boerjan, W., Cervera, M.-T., Delarue, M., Beeckman, T., Dewitte, W., Bellini, C., et al. (1995). Superroot, a recessive mutation in Arabidopsis, confers auxin overproduction. Plant Cell 7, 1405-1419.

Brady, S. M., Orlando, D. A., Lee, J.-Y., Wang, J. Y., Koch, J., Dinneny, J. R., et al. (2007). A high-resolution root spatiotemporal map reveals dominant expression patterns. Science 318, 801-806. doi: 10.1126/science.1146265

Brady, S. M., Sarkar, S. F., Bonetta, D., and McCourt, P. (2003). The ABSCISIC ACID INSENSITIVE 3 (ABI3) gene is modulated by farnesylation and is involved in auxin signalling and lateral root development in Arabidopsis. Plant J. 34, 67-75. doi: 10.1046/j.1365-313X.2003.01707.x

Busch, W., Moore, B. T., Martsberger, B., Mace, D. L., Twigg, R. W., Jung, J., et al. (2012). A microfluidic device and computational platform for highthroughput live imaging of gene expression. Nat. Methods 9, 1101-1106. doi: 10.1038/nmeth. 2185

Casimiro, I., Beeckman, T., Graham, N., Bhalerao, R., Zhang, H., Casero, P., et al. (2003). Dissecting Arabidopsis lateral root development. Trends Plant Sci. 8, 165-171. doi: 10.1016/S1360-1385(03)00051-7

Celenza, J. L., Grisafi, P. L., and Fink, G. R. (1995). A pathway for lateral root formation in Arabidopsis thaliana. Genes Dev. 9, 2131-2142. doi: 10.1101/gad.9.17.2131

Cheng, J. C., Seeley, K. A., and Sung, Z. R. (1995). RML1 and RML2, Arabidopsis genes required for cell proliferation at the root tip. Plant Physiol. 107, 365-376. doi: 10.1104/pp.107.2.365

Christensen, S. K., Dagenais, N., Chory, J., and Weigel, D. (2000). Regulation of auxin response by the protein kinase PINOID. Cell 100, 469-478. doi: $10.1016 /$ S0092-8674(00)80682-0
Coates, J. C., Laplaze, L., and Haseloff, J. (2006). Armadillo-related proteins promote lateral root development in Arabidopsis. Proc. Natl. Acad. Sci. U.S.A. 103, 1621-1626. doi: 10.1073/pnas.0507575103

Cruz-Ramírez, A., López-Bucio, J., Ramirez-Pimentel, G., Zurita-Silva, A., Sánchez-Calderon, L., Ramírez-Chávez, E., et al. (2004). The xipotl mutant of Arabidopsis reveals a critical role for phospholipid metabolism in root system development and epidermal cell integrity. Plant Cell 16, 2020-2034. doi: 10.1105/tpc.103.018648

Dean, G., Casson, S., and Lindsey, K. (2004). KNAT6 gene of Arabidopsis is expressed in roots and is required for correct lateral root formation. Plant Mol. Biol. 54, 71-84. doi: 10.1023/B:PLAN.0000028772.22892.2d

Delarue, M., Prinsen, E., Onckelen, H. V., Caboche, M., and Bellini, C. (1998). Sur2 mutations of Arabidopsis thaliana define a new locus involved in the control of auxin homeostasis. Plant J. 14, 603-611. doi: 10.1046/j.1365-313X.1998.00163.x

Den Herder, G., Van Isterdael, G., Beeckman, T., and De Smet, I. (2010). The roots of a new green revolution. Trends Plant Sci. 15, 600-607. doi: 10.1016/j.tplants.2010.08.009

De Rybel, B., Audenaert, D., Xuan, W., Overvoorde, P., Strader, L. C., Kepinski, S., et al. (2012). A role for the root cap in root branching revealed by the non-auxin probe naxillin. Nat. Chem. Biol. 8, 798-805. doi: 10.1038/nchembio. 1044

De Rybel, B., Vassileva, V., Parizot, B., Demeulenaere, M., Grunewald, W., Audenaert, D., et al. (2010). A novel Aux/IAA28 signaling cascade activates GATA23-dependent specification of lateral root founder cell identity. Curr. Biol. 20, 1697-1706. doi: 10.1016/j.cub.2010.09.007

De Smet, I., Tetsumura, T., De Rybel, B., Frey, N. F. D., Laplaze, L., Casimiro, I., et al. (2007). Auxin-dependent regulation of lateral root positioning in the basal meristem of Arabidopsis. Development 134, 681-690. doi: 10.1242/dev.02753

De Smet, I., Vanneste, S., Inze, D., and Beeckman, T. (2006). Lateral root initiation or the birth of a new meristem. Plant Mol. Biol. 60, 871-887. doi: 10.1007/s11103-005-4547-2

De Smet, I., Vassileva, V., De Rybel, B., Levesque, M. P., Grunewald, W., Van Damme, D., et al. (2008). Receptor-like kinase ACR4 restricts formative cell divisions in the Arabidopsis root. Science 322, 594-597. doi: 10.1126/science. 1160158

Dharmasiri, N., Dharmasiri, S., Weijers, D., Lechner, E., Yamada, M., Hobbie, L., et al. (2005). Plant development is regulated by a family of auxin receptor F Box proteins. Dev. Cell 9, 109-119. doi: 10.1016/j.devcel.2005.05.014

DiDonato, R. J., Arbuckle, E., Buker, S., Sheets, J., Tobar, J., Totong, R., et al. (2004). Arabidopsis ALF4 encodes a nuclear-localized protein required for lateral root formation. Plant J. 37, 340-353. doi: 10.1046/j.1365-313X.2003.01964.x

Ditengou, F. A., Teale, W. D., Kochersperger, P., Flittner, K. A., Kneuper, I., van der Graaff, E., et al. (2008). Mechanical induction of lateral root initiation in Arabidopsis thaliana. Proc. Natl. Acad. Sci. U.S.A. 105, 18818-18823. doi: 10.1073/pnas.0807814105

Dong, L. Wang, L., Zhang, Y., Zhang, Y., Deng, X., and Xue, Y. (2006). An auxininducible F-box protein CEGENDUO negatively regulates auxin-mediated lateral root formation in Arabidopsis. Plant Mol. Biol. 60, 599-615. doi: 10.1007/s11103-005-5257-5

Duan, L., Dietrich, D., Ng, C. H., Chan, P. M. Y., Bhalerao, R., Bennett, M. J., et al. (2013). Endodermal ABA signaling promotes lateral root quiescence during salt stress in Arabidopsis seedlings. Plant Cell 25, 324-341. doi: 10.1105/tpc.112.107227

Dubrovsky, J. G., Gambetta, G. A., Hernández-Barrera, A., Shishkova, S., and González, I. (2006). Lateral root initiation in Arabidopsis: developmental window, spatial patterning, density and predictability. Ann. Bot. 97, 903-915. doi: 10.1093/aob/mcj604

Dubrovsky, J. G., Napsucialy-Mendivil, S., Duclercq, J., Cheng, Y., Shishkova, S., Ivanchenko, M. G., et al. (2011). Auxin minimum defines a developmental window for lateral root initiation. New Phytol. 191, 970-983. doi: 10.1111/j.1469-8137.2011.03757.x

Dubrovsky, J. G., Sauer, M., Napsucialy-Mendivil, S., Ivanchenko, M. G., Friml, J., Shishkova, S., et al. (2008). Auxin acts as a local morphogenetic trigger to specify lateral root founder cells. Proc. Natl. Acad. Sci. U.S.A. 105, 8790-8794. doi: 10.1073/pnas.0712307105

Faure, J. D., Vittorioso, P., Santoni, V., Fraisier, V., Prinsen, E., Barlier, I., et al. (1998). The PASTICCINO genes of Arabidopsis thaliana are involved in the control of cell division and differentiation. Development 125, 909-918.

Fukaki, H., Tameda, S., Masuda, H., and Tasaka, M. (2002). Lateral root formation is blocked by a gain-of-function mutation in the SOLITARY-ROOT/IAA14 
gene of Arabidopsis. Plant J. 29, 153-168. doi: 10.1046/j.0960-7412.2001. 01201.x

Fukaki, H., Taniguchi, N., and Tasaka, M. (2006). PICKLE is required for SOLITARY-ROOT/IAA14-mediated repression of ARF7 and ARF19 activity during Arabidopsis lateral root initiation. Plant J. 48, 380-389. doi: 10.1111/j.1365-313X.2006.02882.x

Fukaki, H., and Tasaka, M. (2009). Hormone interactions during lateral root formation. Plant Mol. Biol. 69, 437-449. doi: 10.1007/s11103-008-9417-2

Gaedeke, N., Klein, M., Kolukisaoglu, U., Forestier, C., Müller, A., Ansorge, M., et al. (2001). The Arabidopsis thaliana ABC transporter AtMRP5 controls root development and stomata movement. EMBO J. 20, 1875-1887. doi: 10.1093/emboj/20.8.1875

Galkovskyi, T., Mileyko, Y., Bucksch, A., Moore, B., Symonova, O., Price, C., et al. (2012). GiA Roots: software for the high throughput analysis of plant root system architecture. BMC Plant Biol. 12:116. doi: 10.1186/1471-2229-12-116

Geldner, N., Richter, S., Vieten, A., Marquardt, S., Torres-Ruiz, R. A., Mayer, U., et al. (2004). Partial loss-of-function alleles reveal a role for GNOM in auxin transport-related, post-embryonic development of Arabidopsis. Development 131, 389-400. doi: 10.1242/dev.00926

Gil, P., Dewey, E., Friml, J., Zhao, Y., Snowden, K. C., Putterill, J., et al. (2001). BIG: a calossin-like protein required for polar auxin transport in Arabidopsis. Genes Dev. 15, 1985-1997. doi: 10.1101/gad.905201

Gray, W. M., Muskett, P. R., Chuang, H. W., and Parker, J. E. (2003). Arabidopsis SGT1b is required for SCF(TIR1)-mediated auxin response. Plant Cell 15, 1310-1319. doi: 10.1105/tpc.010884

Gupta, S., Shi, X., Lindquist, I. E., Devitt, N., Mudge, J., and Rashotte, A. M. (2013). Transcriptome profiling of cytokinin and auxin regulation in tomato root. J. Exp. Bot. 64, 695-704. doi: 10.1093/jxb/ers365

Guyomarc'h, S., Leran, S., Auzon-Cape, M., Perrine-Walker, F., Lucas, M., and Laplaze, L. (2012). Early development and gravitropic response of lateral roots in Arabidopsis thaliana. Philos. Trans. R. Soc. Lond. B Biol. Sci. 367, 1509-1516. doi: 10.1098/rstb.2011.0231

Hennig, L., Menges, M., Murray, J. A., and Gruissem, W. (2003). Arabidopsis transcript profiling on Affymetrix GeneChip arrays. Plant Mol. Biol. 53, 457-465. doi: 10.1023/B:PLAN.0000019069.23317.97

Himanen, K., Boucheron, E., Vanneste, S., de Almeida Engler, J., Inzé, D., and Beeckman, T. (2002). Auxin-mediated cell cycle activation during early lateral root initiation. Plant Cell 14, 2339-2351. doi: 10.1105/tpc.004960

Himanen, K., Vuylsteke, M., Vanneste, S., Vercruysse, S., Boucheron, E., Alard, P., et al. (2004). Transcript profiling of early lateral root initiation. Proc. Natl. Acad. Sci. U.S.A. 101, 5146-5151. doi: 10.1073/pnas.0308702101

Hobbie, L., and Estelle, M. (1995). The axr4 auxin-resistant mutants of Arabidopsis thaliana define a gene important for root gravitropism and lateral root initiation. Plant J. 7, 211-220. doi: 10.1046/j.1365-313X.1995.7020211.x

Hobbie, L., McGovern, M., Hurwitz, L. R., Pierro, A., Liu, N. Y., Bandyopadhyay, A., et al. (2000). The axr6 mutants of Arabidopsis thaliana define a gene involved in auxin response and early development. Development 127, 23-32.

Hu, Y. X., Wang, Y. X., Liu, X. F., and Li, J. Y. (2004). Arabidopsis RAV1 is downregulated by brassinosteroid and may act as a negative regulator during plant development. Cell Res. 14, 8-15. doi: 10.1038/sj.cr.7290197

Hubberten, H. M., Drozd, A., Tran, B. V., Hesse, H., and Hoefgen, R. (2012). Local and systemic regulation of sulfur homeostasis in roots of Arabidopsis thaliana: Regulation of sulfur homeostasis in Arabidopsis roots. Plant J. 72, 625-635. doi: 10.1111/j.1365-313X.2012.05105.x

Ikeyama, Y., Tasaka, M., and Fukaki, H. (2010). RLF, a cytochrome b5-like heme/steroid binding domain protein, controls lateral root formation independently of ARF7/19-mediated auxin signaling in Arabidopsis thaliana. Plant J. 62, 865-875. doi: 10.1111/j.1365-313X.2010.04199.x

Kanyuka, K., Praekelt, U., Franklin, K. A., Billingham, O. E., Hooley, R., Whitelam, G. C., et al. (2003). Mutations in the huge Arabidopsis gene BIG affect range of hormone and light responses. Plant J. 35, 57-70. doi: 10.1046/j.1365313X.2003.01779. $\mathrm{x}$

Kim, S. H., Arnold, D., Lloyd, A., and Roux, S. J. (2001). Antisense expression of an Arabidopsis ran binding protein renders transgenic roots hypersensitive to auxin and alters auxin-induced root growth and development by arresting mitotic progress. Plant Cell 13, 2619-2630. doi: 10.1105/tpc.010214

King, J. J., Stimart, D. P., Fisher, R. H., and Bleecker, A. B. (1995). A mutation altering auxin homeostasis and plant morphology in Arabidopsis. Plant Cell 7 , 2023-2037.
Kumpf, R. P., Shi, C.-L., Larrieu, A., Sto, I. M., Butenko, M. A., Peret, B., et al. (2013). Floral organ abscission peptide IDA and its HAE/HSL2 receptors control cell separation during lateral root emergence. Proc. Natl. Acad. Sci. U.S.A. 110, 5235-5240. doi: 10.1073/pnas.1210835110

Lally, D., Ingmire, P., Tong, H. Y., and He, Z. H. (2001). Antisense expression of a cell wall-associated protein kinase, WAK4, inhibits cell elongation and alters morphology. Plant Cell 13, 1317-1331. doi: 10.1105/TPC.010075

Lan, P., Li, W., Lin, W.-D., Santi, S., and Schmidt, W. (2013). Mapping gene activity of Arabidopsis root hairs. Genome Biol. 14:R67. doi: 10.1186/gb-2013-146-r67

Laplaze, L., Benkova, E., Casimiro, I., Maes, L., Vanneste, S., Swarup, R., et al. (2007). Cytokinins act directly on lateral root founder cells to inhibit root initiation. Plant Cell 19, 3889-3900. doi: 10.1105/tpc.107.055863

Laplaze, L., Parizot, B., Baker, A., Ricaud, L., Martinière, A., Auguy, F., et al. (2005). GAL4-GFP enhancer trap lines for genetic manipulation of lateral root development in Arabidopsis thaliana. J. Exp. Bot. 56, 2433-2442. doi: $10.1093 / \mathrm{jxb} / \mathrm{eri236}$

Laskowski, M., Grieneisen, V. A., Hofhuis, H., ten Hove, C. A., Hogeweg, P., Marée, A. F. M., et al. (2008). Root system architecture from coupling cell shape to auxin transport. PLoS Biol. 6:e307. doi: 10.1371/journal.pbio.0060307

Laskowski, M. J., Williams, M. E., Nusbaum, H. C., and Sussex, I. M. (1995). Formation of lateral root meristems is a two-stage process. Development 121, 3303-3310

Lavenus, J., Goh, T., Roberts, I., Guyomarc'h, S., Lucas, M., De Smet, I., et al. (2013). Lateral root development in Arabidopsis: fifty shades of auxin. Trends Plant Sci. 18, 450-458. doi: 10.1016/jtplants.2013.04.006

Li, H., Shen, J. J., Zheng, Z. L., Lin, Y., and Yang, Z. (2001). The Rop GTPase switch controls multiple developmental processes in Arabidopsis. Plant Physiol. 126, 670-684. doi: 10.1104/pp.126.2.670

Li, J. Mo, X., Wang, J., Chen, N., Fan, H., Dai, C., et al. (2009). BREVIS RADIX is involved in cytokinin-mediated inhibition of lateral root initiation in Arabidopsis. Planta 229, 593-603. doi: 10.1007/s00425-008-0854-6

Lincoln, C., Britton, J. H., and Estelle, M. (1990). Growth and development of the axr1 mutants of Arabidopsis. Plant Cell 2, 1071-1080.

Linkohr, B. I., Williamson, L. C., Fitter, A. H., and Leyser, H. M. (2002). Nitrate and phosphate availability and distribution have different effects on root system architecture of Arabidopsis. Plant J. 29, 751-760. doi: 10.1046/j.1365313X.2002.01251.x

López-Bucio, J., Cruz-Ramìrez, A., and Herrera-Estrella, L. (2003). The role of nutrient availability in regulating root architecture. Curr. Opin. Plant Biol. 6, 280-287. doi: 10.1016/S1369-5266(03)00035-9

Lucas, M., Godin, C., Jay-Allemand, C., and Laplaze, L. (2008). Auxin fluxes in the root apex co-regulate gravitropism and lateral root initiation. J. Exp. Bot. 59, 55-66. doi: 10.1093/jxb/erm171

Lucas, M., Kenobi, K., von Wangenheim, D., Vo $\beta$, U., Swarup, K., De Smet, I., et al. (2013). Lateral root morphogenesis is dependent on the mechanical properties of the overlaying tissues. Proc. Natl. Acad. Sci. U.S.A. 110, 5229-5234. doi: $10.1073 /$ pnas. 1210807110

Lukowitz, W., Gillmor, C. S., and Scheible, W.-R. (2000). Positional cloning in Arabidopsis. Why it feels good to have a genome initiative working for you Plant Physiol. 123, 795-806. doi: 10.1104/pp.123.3.795

Luschnig, C., Gaxiola, R. A., Grisafi, P., and Fink, G. R. (1998). EIR1, a root-specific protein involved in auxin transport, is required for gravitropism in Arabidopsis thaliana. Genes Dev. 12, 2175-2187. doi: 10.1101/gad.12.14.2175

Magidin, M., Pittman, J. K., Hirschi, K. D., and Bartel, B. (2003). ILR2, a novel gene regulating IAA conjugate sensitivity and metal transport in Arabidopsis thaliana. Plant J. 35, 523-534. doi: 10.1046/j.1365-313X.2003.01826.x

Malamy, J. E. (2005). Intrinsic and environmental response pathways that regulate root system architecture. Plant Cell Environ. 28, 67-77. doi: 10.1111/j.1365 3040.2005.01306.x

Malamy, J. E., and Benfey, P. N. (1997). Organization and cell differentiation in lateral roots of Arabidopsis thaliana. Development 124, 33-44.

Malamy, J. E., and Ryan, K. S. (2001). Environmental regulation of lateral root initiation in Arabidopsis. Plant Physiol. 127, 899-909. doi: 10.1104/pp.0 10406

Mallory, A. C., Bartel, D. P., and Bartel, B. (2005). MicroRNA-directed regulation of Arabidopsis AUXIN RESPONSE FACTOR17 is essential for proper development and modulates expression of early auxin response genes. Plant Cell 17, 1360-1375. doi: 10.1105/tpc.105.031716 
Marchant, A., Bhalerao, R., Casimiro, I., Eklof, J., Casero, P. J., Bennett, M., et al. (2002). AUX1 promotes lateral root formation by facilitating indole-3-acetic acid distribution between sink and source tissues in the Arabidopsis seedling. Plant Cell 14, 589-597. doi: 10.1105/tpc.010354

Marhavý, P., Bielach, A., Abas, L., Abuzeineh, A., Duclercq, J., Tanaka, H., et al. (2011). Cytokinin modulates endocytic trafficking of PIN1 auxin efflux carrier to control plant organogenesis. Dev. Cell 21, 796-804. doi: 10.1016/j.devcel.2011.08.014

Marhavý, P., Vanstraelen, M., De Rybel, B., Zhaojun, D., Bennett, M. J., Beeckman, T., et al. (2013). Auxin reflux between the endodermis and pericycle promotes lateral root initiation. EMBO J. 32, 149-158. doi: 10.1038/emboj.2012.303

Moreno-Risueno, M. A., Van Norman, J. M., Moreno, A., Zhang, J., Ahnert, S. E., and Benfey, P. N. (2010). Oscillating gene expression determines competence for periodic arabidopsis root branching. Science 329, 1306-1311. doi: $10.1126 /$ science. 1191937

Mravec, J., Kubes, M., Bielach, A., Gaykova, V., Petrasek, J., Skupa, P., et al. (2008). Interaction of PIN and PGP transport mechanisms in auxin distribution-dependent development. Development 135, 3345-3354. doi: 10.1242/dev.021071

Muraro, D., Byrne, H., King, J., and Bennett, M. (2013). The role of auxin and cytokinin signalling in specifying the root architecture of Arabidopsis thaliana. J. Theor. Biol. 317, 71-86. doi: 10.1016/j.jtbi.2012.08.032

Muraro, D., Byrne, H., King, J., Voß, U., Kieber, J., and Bennett, M. (2011). The influence of cytokinin-auxin cross-regulation on cell-fate determination in Arabidopsis thaliana root development. J. Theor. Biol. 283, 152-167. doi: 10.1016/j.jtbi.2011.05.011

Nagpal, P., Walker, L. M., Young, J. C., Sonawala, A., Timpte, C., Estelle, M., et al. (2000). AXR2 encodes a member of the Aux/IAA protein family. Plant Physiol. 123, 563-574. doi: 10.1104/pp.123.2.563

Nakazawa, M., Yabe, N., Ichikawa, T., Yamamoto, Y. Y., Yoshizumi, T., Hasunuma, K., et al. (2001). DFL1, an auxin-responsive GH3 gene homologue, negatively regulates shoot cell elongation and lateral root formation, and positively regulates the light response of hypocotyl length. Plant J. 25, 213-221. doi: 10.1046/j.1365-313x.2001.00957.x

Nodzon, L. A., Xu, W. H., Wang, Y., Pi, L. Y., Chakrabarty, P. K., and Song, W. Y. (2004). The ubiquitin ligase XBAT32 regulates lateral root development in Arabidopsis. Plant J. 40, 996-1006. doi: 10.1111/j.1365-313X.2004.02266.x

Okushima, Y., Overvoorde, P. J., Arima, K., Alonso, J. M., Chan, A., Chang, C., et al. (2005). Functional genomic analysis of the AUXIN RESPONSE FACTOR gene family members in Arabidopsis thaliana: unique and overlapping functions of ARF7 and ARF19. Plant Cell 17, 444-463. doi: 10.1105/tpc.104.028316

Oyama, T., Shimura, Y., and Okada, K. (1997). The Arabidopsis HY5 gene encodes a bZIP protein that regulates stimulus induced development of root and hypocotyl. Genes Dev. 11, 2983-2995. doi: 10.1101/gad.11.22.2983

Parizot, B., De Rybel, B., and Beeckman, T. (2010). VisuaLRTC: A new view on lateral root initiation by combining specific transcriptome data sets. Plant Physiol. 153, 34-40. doi: 10.1104/pp.109.148676

Péret, B., De Rybel, B., Casimiro, I., Benková, E., Swarup, R., Laplaze, L., et al. (2009). Arabidopsis lateral root development: an emerging story. Trends Plant Sci. 14, 399-408. doi: 10.1016/j.tplants.2009.05.002

Péret, B., Li, G., Zhao, J., Band, L. R., Voß, U., Postaire, O., et al. (2012). Auxin regulates aquaporin function to facilitate lateral root emergence. Nat. Cell Biol. 14, 991-998. doi: 10.1038/ncb2573

Péret, B., Middleton, A. M., French, A. P., Larrieu, A., Bishopp, A., Njo, M., et al. (2013). Sequential induction of auxin efflux and influx carriers regulates lateral root emergence. Mol. Syst. Biol. 9, 699. doi: 10.1038/msb.2013.43

Pfluger, J., and Zambryski, P. (2004). The role of SEUSS in auxin response and floral organ patterning. Development 131, 4697-4707. doi: 10.1242/dev.01306

Pound, M. P., French, A. P., Atkinson, J. A., Wells, D. M., Bennett, M. J., and Pridmore, T. (2013). RootNav: navigating images of complex root architectures. Plant Physiol. 162, 1802-1814. doi: 10.1104/pp.113.221531

Poupart, J., and Waddell, C. S. (2000). The ribl mutant is resistant to indole-3butyric acid, an endogenous auxin in Arabidopsis. Plant Physiol. 124, 1739-1751. doi: 10.1104/pp.124.4.1739

Prusinkiewicz, P., and Runions, A. (2012). Computational models of plant development and form. New Phytol. 193, 549-569. doi: 10.1111/j.14698137.2011.04009.x

Rampey, R. A., LeClere, S., Kowalczyk, M., Ljung, K., Sandberg, G., and Bartel, B. (2004). A family of auxin-conjugate hydrolases that contributes to free indole-3-acetic acid levels during Arabidopsis germination. Plant Physiol. 135, 978-988. doi: 10.1104/pp.104.039677

Rashotte, A. M., DeLong, A., and Muday, G. K. (2001). Genetic and chemical reductions in protein phosphatase activity alter auxin transport, gravity response, and lateral root growth. Plant Cell 13, 1683-1697. doi: 10.1105/TPC.0 10158

Robert, S., Raikhel, N. V., and Hicks, G. R. (2009). Powerful partners: Arabidopsis and chemical genomics. Arabidopsis Book 7:e0109. doi: 10.1199/tab.0109

Rogg, L. E., Lasswell, J., and Bartel, B. (2001). A gain-of-function mutation in IAA28 suppresses lateral root development. Plant Cell 13, 465-480. doi: 10.1105/tpc.13.3.465

Rosquete, M. R., von Wangenheim, D., Marhavý, P., Barbez, E., Stelzer, E. H. K., Benková, E., et al. (2013). An auxin transport mechanism restricts positive orthogravitropism in lateral roots. Curr. Biol. 23, 817-822. doi: 10.1016/j.cub.2013.03.064

Ruegger, M., Dewey, E., Gray, W. M., Hobbie, L., Turner, J., and Estelle, M. (1998). The TIR1 protein of Arabidopsis functions in auxin response and is related to human SKP2 and yeast grrlp. Genes Dev. 12, 198-207. doi: 10.1101/gad.12.2.198

Ruegger, M., Dewey, E., Hobbie, L., Brown, D., Bernasconi, P., Turner, J., et al. (1997). Reduced naphthylphthalamic acid binding in the tir3 mutant of Arabidopsis is associated with a reduction in polar auxin transport and diverse morphological defects. Plant Cell 9, 745-757.

Santelia, D. Vincenzetti, V., Azzarello, E., Bovet, L., Fukao, Y., Düchtig, P., et al. (2005). MDR-like ABC transporter AtPGP4 is involved in auxin-mediated lateral root and root hair development. FEBS Lett 579, 5399-5406. doi: 10.1016/j.febslet.2005.08.061

Sanz, L., Dewitte, W., Forzani, C., Patell, F., Nieuwland, J., Wen, B., et al. (2011). The Arabidopsis D-Type cyclin CYCD2;1 and the inhibitor ICK2/KRP2 modulate auxin-induced lateral root formation. Plant Cell 23, 641-660. doi: 10.1105/tpc. 110.080002

Sawa, S., Ohgishi, M., Goda, H., Higuchi, K., Shimada, Y., Yoshida, S., et al. (2002). The HAT2 gene, a member of the HD-Zip gene family, isolated as an auxin inducible gene by DNA microarray screening, affects auxin response in Arabidopsis. Plant J. 32, 1011-1022. doi: 10.1046/j.1365-313X.2002.01488.x

Schneeberger, K., Ossowski, S., Lanz1, C., Juul, T., Høgh Petersen, A., Lehmann Nielsen, K., et al. (2009). SHOREmap: simultaneous mapping and mutation identification by deep sequencing. Nat. Methods 6, 550-551. doi: 10.1038/nmeth0809-550

Schneeberger, K., and Weigel, D. (2011). Fast-forward genetics enabled by new sequencing technologies. Trends Plant Sci. 16, 282-288. doi: 10.1016/j.tplants.2011.02.006

Seo, M. Akaba, S., Oritani, T., Delarue, M., Bellini, C., Caboche, M., et al. (1998). Higher activity of an aldehyde oxidase in the auxin-overproducing superroot1 mutant of Arabidopsis thaliana. Plant Physiol. 116, 687-693. doi: 10.1104/pp.116.2.687

Signora, L., De Smet, I., Foyer, C. H., and Zhang, H. (2001). ABA plays a central role in mediating the regulatory effects of nitrate on root branching in Arabidopsis. Plant J. 28, 655-662. doi: 10.1046/j.1365-313x.2001.01185.x

Steindler, C., Matteucci, A., Sessa, G., Weimar, T., Ohgishi, M., Aoyama, T., et al. (1999). Shade avoidance responses are mediated by the ATHB-2 HD-zip protein, a negative regulator of gene expression. Development 126, 4235-4245.

Subramanian, S., Rajagopal, B., and Rock, C. D. (2002). Harlequin (hlq) and short blue root (sbr), two Arabidopsis mutants that ectopically express an abscisic acid- and auxin-inducible transgenic carrot promoter and have pleiotropic effects on morphogenesis. Plant Mol. Biol. 49, 93-105. doi: 10.1023/A:10144724 17150

Swarup, K., Benková, E., Swarup, R., Casimiro, I., Péret, B., Yang, Y., et al. (2008). The auxin influx carrier LAX3 promotes lateral root emergence. Nat. Cell Biol. 10, 946-954. doi: 10.1038/ncb1754

Swarup, R., Kramer, E. M., Perry, P., Knox, K., Leyser, H. M. O., Haseloff, J., et al. (2005). Root gravitropism requires lateral root cap and epidermal cells for transport and response to a mobile auxin signal. Nat. Cell Biol. 7, 1057-1065. doi: $10.1038 /$ ncb1316

Szymanowska-Pulka, J., Potocka, I., Karczewski, J., Jiang, K., Nakielski, J., and Feldman, L. J. (2012). Principal growth directions in development of the lateral root in Arabidopsis thaliana. Ann. Bot. 110, 491-501. doi: 10.1093/aob/mcs 129

Takase, T., Nakazawa, M., Ishikawa, A., Kawashima, M., Ichikawa, T., Takahashi, N., et al. (2004). $y d k 1-D$, an auxin-responsive GH3 mutant that is involved 
in hypocotyl and root elongation. Plant J. 37, 471-483. doi: 10.1046/j.1365313X.2003.01973.x

Tatematsu, K., Kumagai, S., Muto, H., Sato, A., Watahiki, M. K., Harper, R. M., et al. (2004). MASSUGU2 encodes Aux/IAA19, an auxin-regulated protein that functions together with the transcriptional activator NPH4/ARF7 to regulate differential growth responses of hypocotyl and formation of lateral roots in Arabidopsis thaliana. Plant Cell 16, 379-393. doi: 10.1105/tpc.018630

Tian, C. E., Muto, H., Higuchi, K., Matamura, T., Tatematsu, K., Koshiba, T., et al. (2004). Disruption and overexpression of auxin response factor 8 gene of Arabidopsis affect hypocotyl elongation and root growth habit, indicating its possible involvement in auxin homeostasis in light condition. Plant J. 40, 333-343. doi: 10.1111/j.1365-313X.2004.02220.x

Tian, Q., and Reed, J. (1999). Control of auxin-regulated root development by the Arabidopsis thaliana SHY2/IAA3 gene. Development 126, 711-721.

To, J. P., Haberer, G., Ferreira, F. J., Deruere, J., Mason, M. G., Schaller, G. E., et al. (2004). Type-A Arabidopsis response regulators are partially redundant negative regulators of cytokinin signaling. Plant Cell 16, 658-671. doi: 10.1105/tpc.018978

Topp, C. N., Iyer-Pascuzzi, A. S., Anderson, J. T., Lee, C.-R., Zurek, P. R., Symonova, O., et al. (2013). 3D phenotyping and quantitative trait locus mapping identify core regions of the rice genome controlling root architecture. Proc. Natl. Acad. Sci. U.S.A. 110, E1695-E1704. doi: 10.1073/pnas.1304354110

Uehara, T. Okushima, Y., Mimura, T., Tasaka, M., and Fukaki, H. (2008). Domain II mutations in CRANE/IAA18 suppress lateral root formation and affect shoot development in Arabidopsis thaliana. Plant Cell Physiol. 49, 1025-1038. doi: 10.1093/pcp/pcn079

Ullah, H., Chen, J. G., Temple, B., Boyes, D. C., Alonso, J. M., Davis, K. R., et al. (2003). The betasubunit of the Arabidopsis G protein negatively regulates auxininduced cell division and affects multiple developmental processes. Plant Cell 15, 393-409. doi: 10.1105/tpc.006148

Ulmasov, T., Hagen, G., and Guilfoyle, T. J. (1999). Dimerization and DNA binding of auxin response factors. Plant J. 19, 309-319. doi: 10.1046/j.1365313X.1999.00538.x

Vanneste, S., De Rybel, B., Beemster, G. T. S., Ljung, K., De Smet, I., Van Isterdael, G. V., et al. (2005). Cell cycle progression in the pericycle is not sufficient for SOLITARY ROOT/IAA14-mediated lateral root initiation in Arabidopsis thaliana. Plant Cell 17, 3035-3050. doi: 10.1105/tpc.105.035493

Vartanian, N. (1996). Mutants as tools to understand cellular and molecular drought tolerance mechanisms. Plant Growth Regul. 20, 125-134. doi: 10.1007/BF00024009

Vittorioso, P., Cowling, R., Faure, J. D., Caboche, M., and Bellini, C. (1998). Mutation in the Arabidopsis PASTICCINO1 gene, which encodes a new
FK506-binding protein-like protein has a dramatic effect on plant development. Mol. Cell Biol. 18, 3034-3043.

Wang, J. W. Wang, L.-J., Mao, Y.-B., Cai, W.-J., Xue, H.-W., and Chen, X.-Y. (2005). Control of root cap formation by microRNA-targeted auxin response factors in Arabidopsis. Plant Cell 17, 2204-2216. doi: 10.1105/tpc.105.033076

Wang, Z., Gerstein, M., and Snyder, M. (2009). RNA-Seq: a revolutionary tool for transcriptomics. Nat. Rev. Genet. 10, 57-63. doi: 10.1038/nrg2484

Werner, T., Motyka, V., Laucou, V., Smets, R., Van Onckelen, H., and Schmulling, T. (2003). Cytokinin-deficient transgenic Arabidopsis plants show multiple developmental alterations indicating opposite functions of cytokinins in the regulation of shoot and root meristem activity. Plant Cell 15, 2532-2550. doi: $10.1105 /$ tpc. 014928

Willemsen, V., Wolkenfelt, H., de Vrieze, G., Weisbeek, P., and Scheres, B. (1998). The HOBBIT gene is required for formation of the root meristem in the Arabidopsis embryo. Development 125, 521-531.

Xie, Q., Guo, H. S., Dallman, G., Fang, S., Weissman, A. M., and Chua, N. H. (2002). SINAT5 promotes ubiquitin-related degradation of NAC1 to attenuate auxin signals. Nature 419, 167-170. doi: 10.1038/nature00998

Yang, X., Lee, S., So, J. H., Dharmasiri, S., Dharmasiri, N., Ge, L., et al. (2004). The IAA1 protein is encoded by AXR5 and is a substrate of SCFTIR1. Plant J. 40, 772-782. doi: 10.1111/j.1365-313X.2004.02254.x

Zolman, B. K., Silva, I. D., and Bartel, B. (2001). The Arabidopsis pxal mutant is defective in an ATP-binding cassette transporter- like protein required for peroxisomal fatty acid betaoxidation. Plant Physiol. 127, 1266-1278. doi: $10.1104 / \mathrm{pp} .010550$

Conflict of Interest Statement: The authors declare that the research was conducted in the absence of any commercial or financial relationships that could be construed as a potential conflict of interest.

Received: 20 September 2013; accepted: 11 December 2013; published online: 26 December 2013.

Citation: Cuesta C, Wabnik Kand Benková E (2013) Systems approaches to study root architecture dynamics. Front. Plant Sci. 4:537. doi: 10.3389/fpls.2013.00537

This article was submitted to Plant Systems Biology, a section of the journal Frontiers in Plant Science.

Copyright () 2013 Cuesta, Wabnik and Benková. This is an open-access article distributed under the terms of the Creative Commons Attribution License (CC BY). The use, distribution or reproduction in other forums is permitted, provided the original author(s) or licensor are credited and that the original publication in this journal is cited, in accordance with accepted academic practice. No use, distribution or reproduction is permitted which does not comply with these terms. 